to sixteen. Two more hospitals should be built, one in Scoresbysund and the other at Angmagssalik, and most of the existing hospitals should be enlarged and given better equipment. Furthermore, it was proposed that two " $\mathrm{X}$-Ray boats" should be built to travel round the settlements in order to combat tuberculosis. In this connection more work should be done to raise the standard of hygiene and to improve the general condition of housing in Greenland.

Finally the report dealt with various cultural problems. Efforts to extend the knowledge of Danish should be intensified, some more Danish teachers should be appointed and more Greenlanders should be given the opportunity of further education in Denmark. It was proposed to establish some new boarding schools where the classes would be held in Danish only. There is a widespread demand for further Danish education in Greenland and it was felt that this would lead to closer association between Danes and Greenlanders. An inspector of educational and cultural affairs should be appointed who would share in the supervision of the education system and would help with the introduction of more cinemas, films and extended wireless facilities.

The report also dealt with many other problems which should have farreaching effects in Greenland. It recommended increased wages both for Greenlanders and Danes in many different appointments. Gronlands Styrelse has already agreed to increase the range of goods available in the shops. Greenlanders will in future be permitted to work in the cryolite mine at Ivigtut as "B Class workers". The coal mining at Kutdligssat is to be continued, but at present the marble quarry at Marmorilik will not be worked.

The report was severely criticised in some quarters in Denmark and it was discussed with some heat in the Greenland Society. The recommendations were thought to be half measures and it was asserted that in many cases no action would be taken until yet another commission had investigated the problem in Greenland itself, thus causing still further delay. All this criticism came out at a time when interest was being taken in the reports of a party of journalists who visited Greenland in September 1946 and who on the whole brought back unsatisfactory reports. But work on the development of Greenland goes on, and several of the recommendations are already being carried out in practice. The Greenlanders are being given more say in their own affairs and the time cannot be far off when they will be able to send their own representatives to the Danish Rigsdag.

J. G. ELBO

\title{
NEW CANADIAN METEOROLOGICAL STATIONS IN THE ARCTIC
}

[The following statement was made in the Canadian House of Commons on 3 March 1947 by the Right Honourable C. D. Howe, Minister of Reconstruction and Supply.]

To enable Canada to provide more accurate and longer-range weather forecasting to meet her domestic and international obligations the Government proposes to establish nine weather stations in the Arctic during the next three years. The most northerly of these will be located in the vicinity of Eureka Sound on the northwestern side of Ellesmere Island approximately 670 miles from the North Pole. The 
main weather station will be established at Winter Harbour on Melville Island at approximately lat. $75^{\circ}$, long. $110^{\circ}$. It is planned to have Eureka Sound and Winter Harbour in operation this coming summer. The actual location of the other weather stations is a matter for further study. It is considered essential that these stations be operated for a minimum period of five years to enable accurate assessment of their value with a view to determining the advisability of continuing or expanding weather reporting operations in these Arctic Regions.

Our Canadian climate and weather is more definitely influenced by currents of air and storms from the Arctic than from any other points of the compass. It is anticipated that the establishment of Arctic weather stations will provide our meteorologists with accurate information which will be of inestimable value to our national economy and particularly to enterprises in many fields such as agriculture and lumbering to say nothing of aviation and other forms of transportation. From an economic point of view, long-range weather forecasting would result in savings far in excess of the monetary costs in establishing and maintaining these stations. Their establishment would also determine the feasibility of air routes across the Polar regions. Reports from the proposed Arctic weather stations will reduce the number of errors in the weather forecasts by providing advance information of outbreaks of cold air from the Far North.

To our knowledge the U.S.S.R., which is equally affected by Polar storms and currents of air as the North American continent, maintains a large number of weather stations in the Arctic.regions on the other side of the North Pole. It is hoped to be able to interchange Arctic weather information with the U.S.S.R. and other neighbouring countries in the North when possible. The U.S.S.R. has already a very extensive exchange of weather information with Canada and will be greatly benefitted by the additional reports which will be made available to them.

These new stations will be of great value to the United States as well as to Canada and their operation' will enable more accurate long-range forecasting by the United States Weather Bureau. The United States has therefore undertaken to assist.Canada in the establishment and operation of these northern stations which will of course be under the control of the Canadian Government who will supply the officers in charge. United States technical personnel will be included in the staffs required. The Canadian Government is grateful for this assistance which will be invaluable until sufficient technically qualified Canadian trained personnel are available. It is believed that this extension of weather-reporting facilities, in which the two countries will co-operate, will be of service to all countries interested in improving our common knowledge of the North land.

In reply to questions in the Canadian House of Commons on 11 June 1947, Mr McIraith gave some further information about these statements. $\mathrm{He}$ stated that, so far as the Department of Transport was concerned, two weather stations in the Canadian Arctic had been established since V-E day-one at Baker Lake (lat. $64^{\circ} 18^{\prime}$ N., long. $96^{\circ} 5^{\prime}$ W.) and the other at Eureka Sound (lat. $80^{\circ} 13^{\prime}$ N., long. $86^{\circ} 11^{\prime}$ W.). In the case of the station at Eureka Sound, the Canadian Government is supplying the officer-in-charge, one-half of the staff and their food. The United States Weather Bureau is supplying the rest of the personnel until sufficiently trained Canadians are available, together with their food supplies, and additional supplies and technical equipment. The United States is also furnishing the necessary transportation for the establishment of this station. The Department of Transport is responsible for the operation of the Eureka Sound station and for the weather programme at 
Baker Lake. The weather programme at Baker Lake is actually performed by Royal Canadian Corps of Signals personnel of the Department of National Defence. There are three Canadians at Eureka Sound and five at Baker Lake. The New York Herald-Tribune reported on 13 April that the Eureka Sound station had sent its first wireless weather report on 12 April 1947.

\section{RECORD LOW. TEMPERATURE IN YUKON TERRITORY}

[Based on notes in The Times, 1 February 1947, and St John's Evening Telegram, and 24 March 1047.]

Early this year the lowest known temperature on the North American continent was recorded at Snag Royal Canadian Air Force station in the Yukon. The published figure, in The Times, was $-78.7^{\circ} \mathrm{F} .\left(-61.5^{\circ} \mathrm{C}.\right)$, and in the Newfoundland paper, $-81^{\circ} \mathrm{F} .\left(-62 \cdot 7^{\circ} \mathrm{C}\right.$.); that is to say approximately $111^{\circ}$ of frost on the Fahrenheit scale. Snag is about 200 miles north-west of Whitehorse and a little east of the Alaskan border. According to The Times report the new record at Snag was one-fifth of a degree lower than the previous minimum recorded at Good Hope, Northwest Territories, in 1910. For comparison, the minimum recorded in Siberia is $-94^{\circ} \mathrm{F} .\left(-70^{\circ} \mathrm{C}\right.$. $)$, at Verkhoyansk, about fifty miles north of the Arctic Circle.

One of the interesting features of the occasion at Snag was greatly increased audibility, both along the surface and from distant aircraft. Another was that the freezing of human breath produced a continuous hissing sound. The breath of a man walking left a trail of vapour several hundred yards in length and lasting several minutes. The breath of a group of dogs produced, at treetop level, a little cloud which remained until the temperature rose to $-60^{\circ} \mathrm{F}$. $\left(-51 \cdot 1^{\circ} \mathrm{C}.\right)$.

\section{EXCHANGES OF HEAT AND TOLERANCE TO COLD IN MEN EXPOSED TO OUTDOOR WEATHER}

[Review of paper by E. F. Adolph and G. W. Molnar in American Journal of Physiology, Vol. 146, No. 4, July 1946, pp. 507-37.]

The authors give an account of a series of experiments in which men were exposed to temperatures varying from warm to bitterly cold. The usual length of exposure was for four hours and the subjects were almost naked. The work was done during the months of September, October and November 1946 on the roof of a five-storey laboratory building in Rochester, New York. Records were kept of the wet and dry bulb temperatures of the external air: wind velocity, cloudiness and the height of the sun above the horizon were measured. Various physiological estimations were made, the more important being pulse rate, blood pressure, skin and internal body temperatures, rate of breathing and oxygen consumption, and the effects of exposure on the concentration of the blood. 